\title{
Management of Tomato Yellow Leaf Curl Virus Through Netting
}

\author{
A. Muqit* and A. M. Akanda \\ ${ }^{1}$ Plant Pathology Division, BARI, Joydebpur, Gazipur-1701, Bangladesh \\ ${ }^{2}$ Department of Plant Pathology, BSMRAU, Salna, Gazipur-1706, Bangladesh \\ * Corresponding author
}

Received: 12 December 2006 Accepted: 18 April 2007

\begin{abstract}
Tomato seedlings were raised in the netted seedbeds before transplanting in order to study the effect of netting on the incidence of Tomato yellow leaf curl virus in the field. Two types of nets, namely, fine (40 mesh) and coarse (10 mesh) and insecticidal spray with imidacloprid @ $0.1 \%$ were used in the experiment. Disease incidence and severity, yield and yield contributing characters were recorded. Results show that the disease incidence was reduced by 12 to $37 \%$ and yield was increased by 5 to $21 \%$ due to netting and pesticidal spray. Of the two types of nets, fine net (40 mesh) was more effective than coarse net (10 mesh).
\end{abstract}

Keywords: TYLCV, netting, imidacloprid, tomato

\section{Introduction}

Tomato yellow leaf curl virus (TYLCV) is one of the most devastating begomoviruses of cultivated tomato in tropical and subtropical regions. TYLCV epidemics are associated with high population of whitefly (Bemisia tabaci) (Lapidot et al., 2001). It is the most damaging and widely distributed virus disease of tomato in Bangladesh (Alam, 1995). Spraying of systemic insecticides is currently practiced by the farmers to manage the disease in the field. But sole dependence on insecticides leads to environmental pollution and it is not effective especially under high disease pressure. Other alternative methods therefore need to be investigated.

It has been reported that, use of fine mesh net in the seed bed to protect seedlings from infestation of vectors can delay and reduce the incidence of TYLCV of tomato (Berlinger et al., 1988; Saikia and Muniyappa, 1989; Haydar et al., 1990; Azam et al., 1997; Wongklom, 1999).
Effectiveness of netting in the seed bed for the management of TYLCV of tomato under the prevailing agroclimatic conditions of Bangladesh is yet to be conclusively found out.

The present study was therefore conducted to assess the efficacy of growing seedlings inside insect proof net for the management of TYLCV of tomato in the field.

\section{Materials and Methods}

The experiment was conducted at the research farm of Bangabandhu Sheikh Mujibur Rahman Agricultural University during winter 2003-04 and 2004-05. Twenty eight day old seedlings of the tomato variety Ratan grown under protective net were transplanted in the main field on December 2. Two types of nets were used in the trial. One was fine net (40 mesh) and the other one coarse net (10 mesh) (Figs. 1 and 2). Five treatments of the experiments were $T_{1}=$ Fine net in the seed bed, $T_{2}=$ Fine net with Admire spray, $\mathrm{T}_{3}=$ Coarse net in the seed bed, $\mathrm{T}_{4}=$ Coarse net 


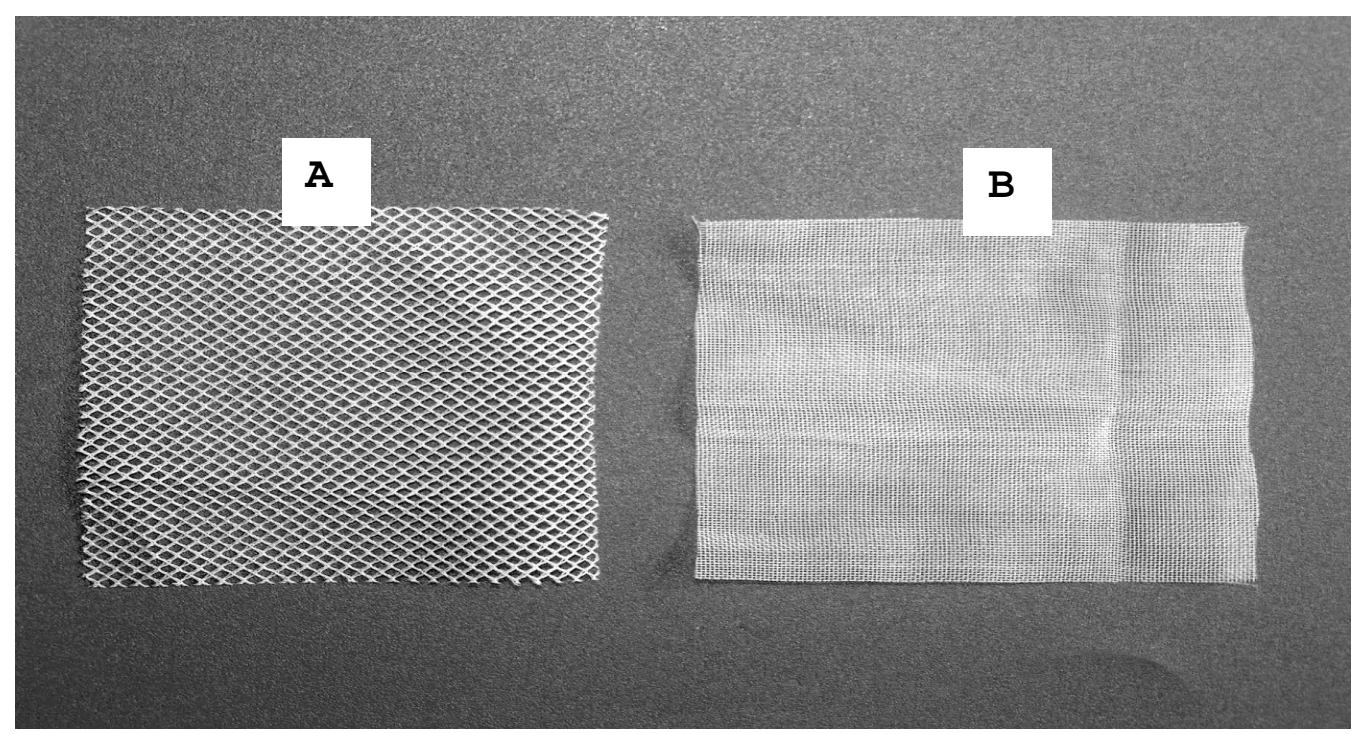

Fig. 1. Coarse (A) and fine (B) net used for protection of seedlings against whitefly.

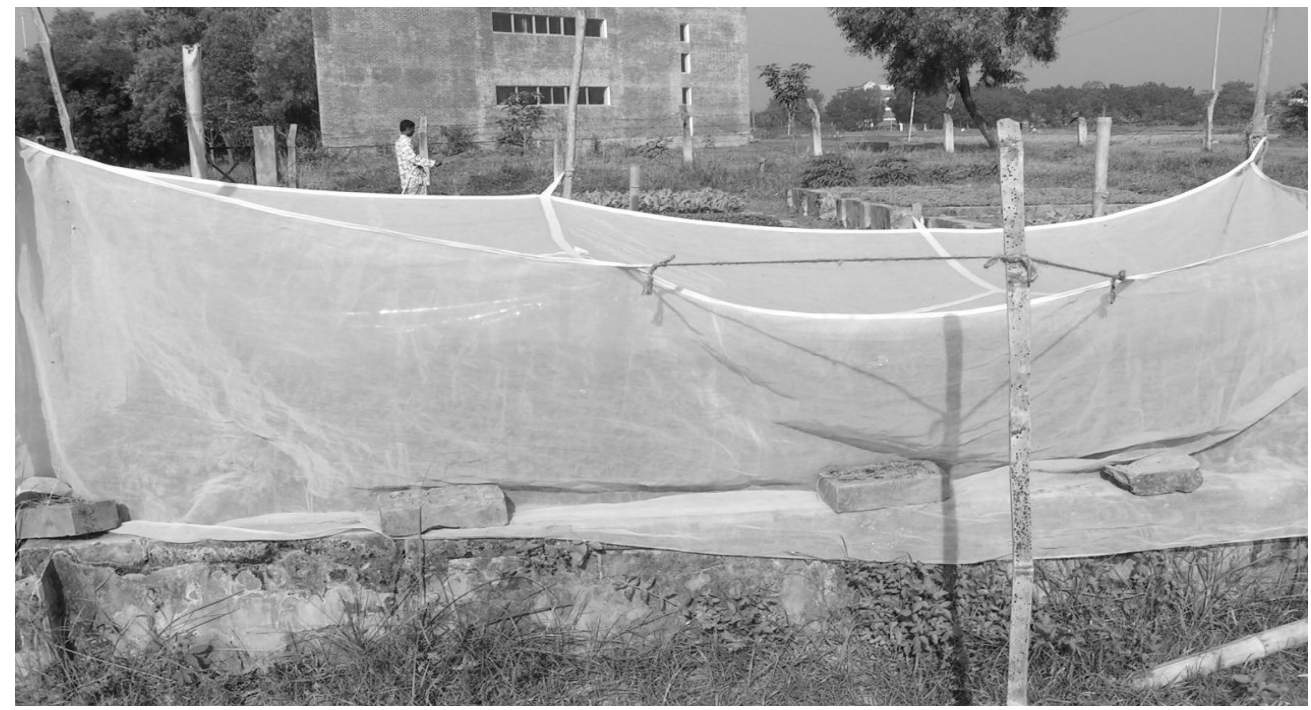

Fig. 2. Use of fine net in the seed bed to exclude whitefly.

with Admire spray and $\mathrm{T}_{5}=$ Control. Imidacloprid (Admire @ 0.1\%) was sprayed three times at 10 days interval against the vector starting from 10 days after transplanting. The disease was identified mainly through visual observation of typical symptoms of TYLCV like upward curling, cupping, with or without marginal chlorosis, smaller leaflets and stunting of the plant (Green and Kalloo, 1994; Sinistera et $a l ., 2000)$. Later on it was confirmed by using commercially available TYLCV identification Kit developed by Neogen Europe Ltd. (UK). The 
protocol followed was according to the manufacturer's recommendation.

Disease incidence was calculated by the standard formula:

Disease incidence $(\%)=\frac{\text { No. of infected plants }}{\text { Total plants in the plot }} X 100$

Disease severity was determined according to Sukkharom (1999) using 1-3 scale as follows:

1 = Light yellowing along the margin, $2=$ Moderate plant stunting, leaf curling or yellowing and $3=$ Severe plant stunting and leaf curling / yellowing.

Plot Severity $S=\frac{n 1+2 n 2+3 n 3}{n 1+n 2+n 3}$

Where ni denotes the number of diseased plants in each grade.

The experiment was laid out in randomized complete block design (RCBD) with 4 replications. Irrigation, staking and other cultural practices were performed as and when necessary. Before analysis, data on disease incidence (\%) were square root transformed.

\section{Results and Discussion}

\subsection{Incidence and severity of TYLCV}

Disease incidence and severity were reduced in all the treatments (Table 1). Significant reduction in disease incidence was obtained with all the treatments except T3. Reduction was more when netting was supplemented in insecticidal spray, but the variation was non-significant. Disease severity was also found to be reduced due to netting but the reduction was non-significant. Among the treatments $\mathrm{T} 2$ was the most effective in reducing the incidence and severity of TYLCV. Fine net was better than the coarse net.

Table 1. Effect of netting on the incidence and severity of TYLCV.

\begin{tabular}{lcc}
\hline \multicolumn{1}{c}{ Treatment } & $\begin{array}{c}\text { Disease Incidence } \\
(\%)\end{array}$ & $\begin{array}{c}\text { Severity } \\
(1-3)\end{array}$ \\
\hline $\mathrm{T}_{1}$ (Fine net) & $16.25 \mathrm{c}$ & 1.46 \\
$\mathrm{~T}_{2}$ (Fine net + spray) & $11.45 \mathrm{c}$ & 1.33 \\
$\mathrm{~T}_{3}$ (Coarse net) & $35.95 \mathrm{ab}$ & 1.55 \\
$\mathrm{~T}_{4}$ (Coarse net + spray) & $23.58 \mathrm{bc}$ & 1.72 \\
$\mathrm{~T}_{5}$ (Control) & $48.44 \mathrm{a}$ & 1.72 \\
\hline
\end{tabular}

(Means followed by same letter are not significantly different at 5\% level by DMRT.)

Table 2. Effect of netting on yield and yield attributes of tomato.

\begin{tabular}{lcccc}
\hline \multirow{2}{*}{ Treatments } & \multicolumn{2}{c}{ Yield } & Fruit No. & Fruit Wt. \\
\cline { 2 - 5 } & (g/plant) & $(\mathrm{t} / \mathrm{ha})$ & $($ No./plant $)$ & $(\mathrm{g} /$ fruit $)$ \\
\hline $\mathrm{T}_{1}$ (Fine net) & 1851.43 & 61.71 & 38.37 & 58.12 \\
$\mathrm{~T}_{2}$ (Fine net with spray) & 1989.12 & 66.30 & 43.01 & 61.54 \\
& 1751.00 & 58.36 & 35.39 & 52.00 \\
$\mathrm{~T}_{3}$ (Coarse net) & 1970.83 & 65.66 & 39.40 & 55.00 \\
$\mathrm{~T}_{4}$ (Coarse net with spray) & 1656.45 & 55.21 & 33.84 & 48.64 \\
& \multicolumn{2}{c}{$\mathrm{NS}$} \\
$\mathrm{T}_{5}$ (Control) & \multicolumn{2}{c}{$\mathrm{NS}$} & $\mathrm{NS}$ \\
\hline
\end{tabular}

(NS: Not significant) 
Table 3. Percent reduction in disease incidence, increase in yield and number of fruits due to netting.

\begin{tabular}{lccc}
\hline \multicolumn{1}{c}{ Treatment } & $\begin{array}{c}\text { Reduction in disease } \\
\text { incidence }(\%)\end{array}$ & $\begin{array}{c}\text { Increase in yield } \\
(\%)\end{array}$ & $\begin{array}{c}\text { Increase in fruit } \\
\text { no. }(\%)\end{array}$ \\
\hline $\mathrm{T}_{1}$ (Fine net) & 32.19 & 11.76 & 13.38 \\
$\mathrm{~T}_{2}$ (Fine net with spray) & 36.99 & 20.07 & 27.09 \\
$\mathrm{~T}_{3}$ (Coarse net) & 12.49 & 05.70 & 04.58 \\
$\mathrm{~T}_{4}$ (Coarse net with spray) & 24.86 & 18.97 & 16.43 \\
$\mathrm{~T}_{5}$ (Control) & --- & --- & --- \\
\hline
\end{tabular}

Table 4. Temporal distribution of TYLCV infected plants in netted and control plots.

\begin{tabular}{lccc}
\hline \multirow{2}{*}{ Treatment } & \multicolumn{3}{c}{ Percent infection after transplanting } \\
\cline { 2 - 4 } & $0-4$ Week & $5-7$ Week & $8-10$ Week \\
\hline $\mathrm{T}_{1}$ (Fine net) & 8 & 30 & 62 \\
$\mathrm{~T}_{2}$ (Fine net with spray) & 0 & 33 & 67 \\
$\mathrm{~T}_{3}$ (Coarse net) & 11 & 33 & 56 \\
$\mathrm{~T}_{4}$ (Coarse net with spray) & 11 & 39 & 50 \\
$\mathrm{~T}_{5}$ (Control) & 16 & 39 & 45 \\
\hline
\end{tabular}

\subsection{Yield}

All the treatments resulted increase in yield though it was non-significant (Table 2). The highest yield was obtained from T2 followed by T4, T1 and T3 while the lowest from the control. Similarly increase in yield contributing characters like number of fruits/plant and average fruit weight did not vary significantly.

\subsection{Disease suppression and yield increase}

Use of nets along with chemical spray resulted in reduction of TYLCV and higher yield and yield contributing characters (Table 3). Percent disease reduction varied from 12.49 to 36.99 and the maximum was found in $\mathrm{T} 2$ and the minimum with T3. Increase in yield and number of fruits varied from 5.70 to 20.07 and 4.58 to $27.09 \%$ respectively.

Production of seedlings under net appreciably reduced the incidence of TYLCV in the field. Exclusion of the vector whitefly (Bemisia tabaci) at this stage seems to be the reason for lower disease incidence in the field. Prevention of the vector at early stage is advantageous in 2 ways, first, if early infection can be avoided then the severity of the disease is minimized. This is very important for the management of virus disease because yield loss due to virus disease is more influenced by severity than incidence. This phenomenon is observed in the present experiment as well. Results of the present experiment indicated that yield and yield contributing characters did not vary significantly (Table 2) despite significant variation in disease incidence (Table 1). It might be due to low disease pressure at initial stage of transplanting. It was also observed that most of the infections took place at later stage (8-10 week after transplanting, Table 4) of the crop growth. This implies that disease severity was not very high during the cropping season as is evident from Table 1 . The other advantage of avoiding early infection is the reduction of source of infection for secondary spread which ultimately leads to lower amount of disease. Findings of the present study are in conformity with the findings of Berlinger et al. (1988); Saikia and Muniyappa (1989); Haydar et al. (1990) and Wongklom (1999). Spraying of Admire in addition to netting further improved the disease situation. This 
implies that in case of high vector population, netting alone is not enough. It should be supplemented with effective chemical spray. But when disease pressure is low netting alone is enough for effective disease management.

\section{Conclusions}

Results of the present investigation demonstrated that raising of seedlings in the net protected nursery or seed bed could be an effective ecofriendly alternative for the management of TYLCV in the field. This could be used as a component of integrated disease management. However, for better result additional 3 sprays of Admire (0.1\%) is suggested.

\section{References}

Alam, N. 1995. Studies on the virus diseases of tomato in Bangladesh. An M Phil thesis submitted to the Department of Botany, Jahangirnagar University, Savar, Dhaka, p.102.

Azam, K. M., Razvil, S. A., Zouba, A. and AlRaeesi, A. A. 1997. Management of whitefly (Bemisia tabaci Gennadius) and tomato leaf curl virus in tomatoes. Arab and Near East Plant Protection Newsletter, 25: 27.

Berlinger, M. J., Dahan, R. and Mordechi, S. 1988. Integrated Pest Management of Organically grown greenhouse tomatoes in Israel. Applied Agricultural Research, 3(5): 233-238.

Green, S. K. and Kalloo, G. 1994. Leaf curl and yellowing viruses of pepper and tomato: an overview. Technical Bulletin No. 21.
Asian Vegetable Research and Development Center, Taiwan. p.51.

Haydar, M.F., Afifi, F.M. and Aly, F.A. 1990. A simple approach for the management of whitefly-borne virus diseases on tomatoes. Bulletin of Faculty of Agriculture, University of Cairo, 41: 649-664.

Lapidot, M., Friedmann, M., Pilowsky, M., BenJoseph, R. and Cohen, S. 2001. Effect of host plant resistance to Tomato yellow leaf curl virus (TYLCV) on virus acquisition and transmission by its whitefly vector. Phytopathology, 91: 1209-1213.

Saikia, A.K. and Muniyappa, V. 1989. Epidemiology and control of tomato leaf curl virus in Southern India. Tropical Agriculture (Trinidad), 66(4): 350-354.

Sinistera, X., Patte, C.P., Siewnath, S. and Polston, J.E. 2000. Identification of TYLCV-Is in the Bahamas. Plant Disease, 84(5): 592.

Sukkharom, A. 1999. Effect of seedling age at transplanting and whitefly chemical control on TYLCV incidence and severity. ARC-AVRDC Training Report 1999. p250. (http : www.arcavrdc.org/pdf_files/sukkharom N).pdf).

Wongklom, W. 1999. Effect of physical barrier on the control of tomato yellow leaf curl virus and its vector (whitefly). ARCAVRDC Training Report 1999. p250. (http: www.arc-avrdc.org/pdf__ files/ wongklom (17-N).pdf) 